\title{
Can the Black bog ant (Formica picea Nyl.) survive in the Bieszczady National Park (SE Poland)?
}

\author{
Abraham A. MABELIS* and Julita KORCZYŃSKA** \\ *Alterra, Wageningen-UR, postbox 47,6700 AA Wageningen, The Netherlands, \\ e-mail:bram.mabelis@wur.nl \\ **Nencki Institute of Experimental Biology, Department of Neurophysiology, Laboratory of Eihology, Pasteura 3, 02- \\ 093 Warsaw, Poland
}

\begin{abstract}
In the peat bogs of the Bieszezady National Park an inventory of the Black bog ant (Formica picea Nyl.) was made in order to get an impression of the probability of its survival in SE Poland. Three habitat networks are distinguished, which are situated too far from each other for (re)colonization by means of flying queens. The largest network includes five peat bogs. In two of them $F$. picea was found. The species was not found in peat bogs which belong to the other habitat networks. The quality of the peat bogs depends on management strategies, currently challenged by two main threats: desiccation and the influx of nutrients. This process will speed up the succession of the vegetation. As a result dwarf shrubs are encroaching on habitat areas of $F$. picea, where Sphagnum species are still dominating in the moss layer.
\end{abstract}

Key words: peat bog, Formicidae, Formica picea, survival, management

\section{INTRODUCTION}

A peat bog ecosystem is vulnerable to desiccation and eutrophication. The presence of stenotopic species, which are characteristic for peat bogs, can be used as indicators of its nature quality. The Black bog ant Formica picea Nyl. (syn. F. transkaucasica Nasonov) is one of them. In Europe this hygrophilic species inhabits peat bogs, wet heath lands and subalpine mountain meadows. In Poland the species is only recorded from peat bogs (Czechowski et al. 2002). It can be considered as a relict species from the ice age. The probability of $F$. picea being present in a peat bog is not only related to the size and quality of habitat patches within that area, but also to the isolated position of that area with regard to nearest peat bogs where the species occurs. The probability of $F$. picea to colonize isolated habitat patches is very low, due to the limited dispersal capacity of its queens (Mabelis \& Chardon 2005). The regional survival chance of the Black bog ant depends upon the ratio between the extinction and (re)colonization rate of local populations (Verboom \& Lankester 1991).

We have chosen the Bieszczady National Park for studying the survival probability of F. picea in a fragmented habitat network. Some peat bogs are so isolated (Fig. 1) that the probability of (re)colonization will be very low. The habitat area within the peat bogs differ considerable in size, which has consequences for the survival of local populations: the larger the size, the higher the survival probability will be (Mabelis \& Chardon 2005). It seems that all bogs contain suitable habitat of F. picea, especially on places where Sphagnum is dominating. The thickness of the peat layer in the bogs varies between 1.5 and $7.4 \mathrm{~m} ; 3.35 \mathrm{~m}$ on average (Haczewski et al. 2007, Marek \& Pałczyński 1962). The ground water level varies in space and time. It is lowest at the end of the summer, but generally not lower than $50 \mathrm{~cm}$ below the surface. An exception is bog number 8 (see Results) with a level of $60-70 \mathrm{~cm}$ below 
the surface. In October the ground water level of the bogs was $0-14 \mathrm{~cm}$ below surface; $5.8 \mathrm{~cm}$ on average (data from 2009, S. Kucharzyk, pers. comm.).

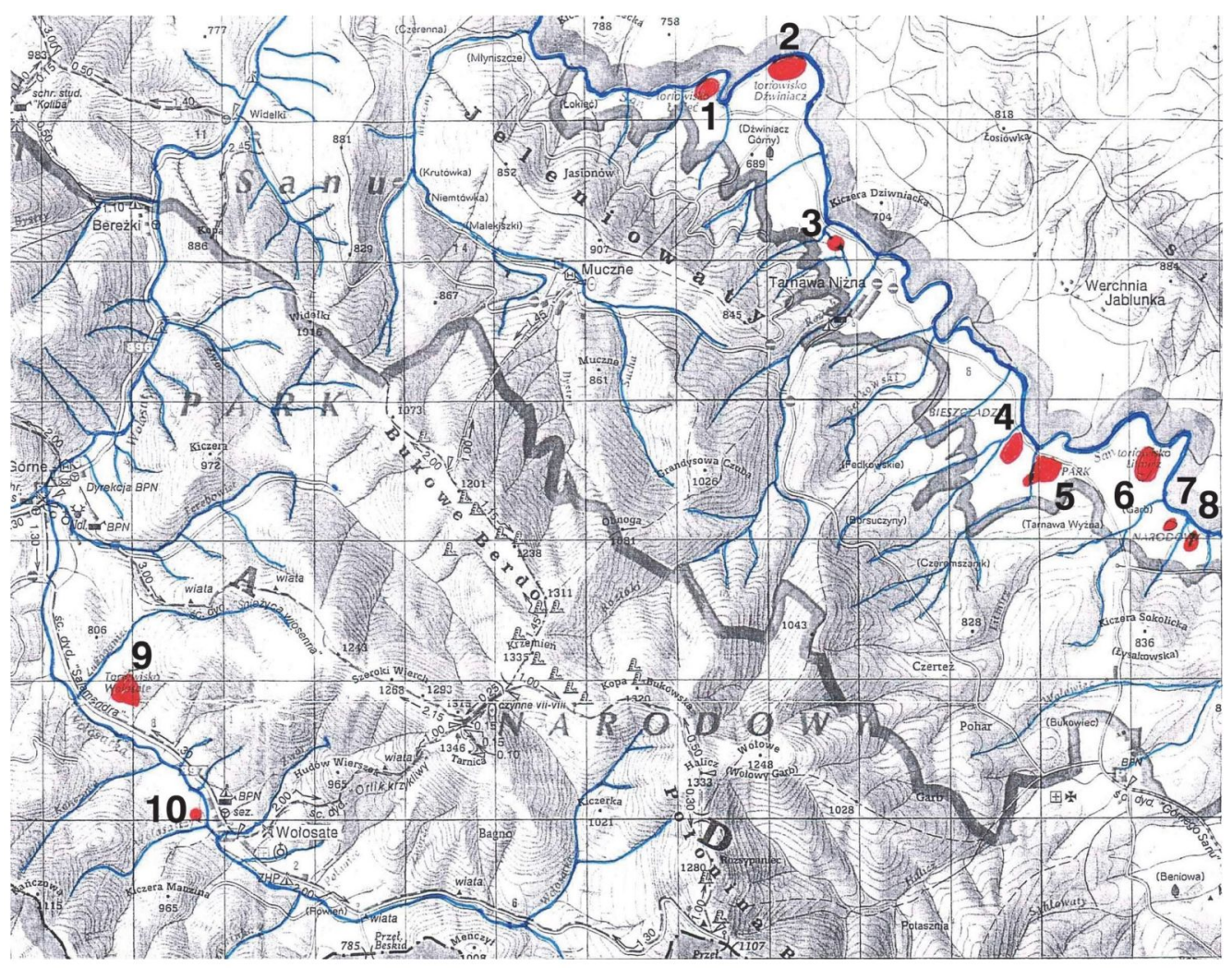

Fig. 1. Distribution of peat bogs in Bieszczady NP: 1 - Łokieć, 2 - Dźwiniacz, 3 - Tarnawa Niżna, 4 - Tarnawa Wyżna A, 5 - Tarnawa Wyżna B, 6 - Litmirz, 7 - Sokoliki Górskie A, 8 - Sokoliki Górskie B, 9 - Rezerwat Wolosate, 10 Wolosate. Blocks: $1 \times 2 \mathrm{~km}$. Area within thick solid line does not belong to the National Park; area in NE part of map (east of river San) belongs to Ukraine.

In order to examine the status and survival probability of the Black bog ant in the Bieszczady NP all its peat bogs were investigated during late summer 2010. This survey could be the beginning for including this species into a monitoring program.

\section{METHOD}

During the survey period 25.8-12.9.2010 ant nests were recorded at sight and by pricking suitable nesting sites with a small shovel. The searching time per area varied from 1 till 3 hours, dependent of the size of the area. Black bog ants are less easily to find than the other species of the genus Formica L., because only a small part of a colony forage above ground in search for prey. A great deal of the food is found under the soil surface, namely fungi and honeydew of root aphids (Bönner 1914, Skwarra 1929). The weather was rather cold and rainy during the investigation period, but this may not have influenced the chance to find nests of the Black bog ant. Specimens of F. picea, F. lemani Bondr. and Lasius platythorax Seifert were collected for correctness of identification in the laboratory. 


\section{RESULTS}

The Black bog ant was only found in two peat bogs (Table 1, Fig. 1, numbers 4 and 6). We did not find this species in peat bog number 5 , where the species was rather common in 1981 and 1985 (A. A. Mabelis, unpublished). Its congeneric species $F$. lemani was found in one bog, while its close relative $F$. fusca L. was found in nearly all peat bogs. The latter species is eurytopic: it occurs in dry as well as wet biotopes. The presence of at least one of these three species, which all belong to the subgenus Serviformica Forel is conditional for the establishment of the other Formica species mentioned in Table 1. Fertilized queens of these species should be adopted by a Serviformica species for establishing a colony, because they are not able to care for her own brood. They are temporary social parasites (Hölldobler \& Wilson 1990). These Formica species occur generally in more dry biotopes, because they are dependent on aphids which live on bushes and trees. The small peat bog number $3(0.7 \mathrm{ha})$, which is for a great deal overgrown by spruce trees, is occupied by the wood ant Formica polyctena Först.: five nests within a small open area of $0.05 \mathrm{ha}$. It implies that no suitable habitat is available for the Black bog ant. A nest of Formica exsecta Nyl. was found in two peat bogs, which are situated about one kilometer from each other. In 1994, this species was found in bog number 9 (A. A. Mabelis, unpublished), but in 2010 only a nest of the Trunk ant Formica truncorum F. was detected.

Table 1. Occurrence of ant species in peat bogs of Bieszczady National Park (SE Poland); +- present; ++ - common

\begin{tabular}{|c|c|c|c|c|c|c|c|c|c|c|c|}
\hline Number of peat bog & 1 & 2 & 3 & 4 & 5 & 6 & 7 & 8 & 9 & 10 & Total \\
\hline Species $\backslash$ Area (ha) & 4,4 & 8,2 & 0,7 & 4,7 & 15,2 & 7,1 & 0,8 & 2 & 2,5 & 0,4 & \\
\hline $\begin{array}{l}\text { Formica picea } \\
\text { Formica lemani }\end{array}$ & & & & ++ & & +++ & + & & & & $\begin{array}{l}2 \\
1\end{array}$ \\
\hline Formica fusca & + & + & + & + & + & + & + & + & + & & 9 \\
\hline Formica rufa & + & + & & & + & + & & & + & + & 6 \\
\hline Formica polyctena & & & + & & & + & & & & & 2 \\
\hline Formica pratensis & & & & & & & & & + & & 1 \\
\hline Formica truncorum & & & & & & & & & + & & 1 \\
\hline Formica sanguinea & & & & & & & & & & + & 1 \\
\hline Formica exsecta & + & + & & & & & & & & & 2 \\
\hline Lasius platythorax & + & ++ & & + & + & + & & & + & + & 7 \\
\hline Lasius flavus & + & & & & + & & & + & + & + & 5 \\
\hline Myrmica ruginodis & & & + & + & & & & + & + & + & 5 \\
\hline Myrmica rubra & & & & & + & & & & + & + & 3 \\
\hline Myrmica scabrinodis & & + & & + & & + & & & & & 3 \\
\hline Total & 5 & 5 & 3 & 5 & 5 & 6 & 2 & 3 & 8 & 6 & \\
\hline
\end{tabular}

Lasius platythorax was found in most peat bogs $(70 \%)$. The species is more common in moist biotopes than its close relative L. niger (L.) Three species of Myrmica were found, but they are eurytopic and not dependent of peat bogs for their survival.

\section{DISCUSSION}

A single population of a $F$. picea nest can stand unfavorable conditions to some extent, because the whole colony can move to a better place at walking distance of the ants. However, a group of interacting colonies will be better off, as they can cooperate and eventually fuse as long as there is regular exchange of workers between the nests. Such exchange will decrease the extinction risk of the queens. A fair proportion of the nests of $F$. picea may be monogynous (one queen), but some colonies will adopt more queens (Pamilo 1982). Polygyny makes it possible to disperse by fission, but also to fuse with another colony. Dispersal over longer distances can only take place by means of flying 
queens. However, most queens will not fly very far (Mabelis \& Chardon 2005). Risky dispersal and low probability of founding a new colony may be the key factors for the development of polygyny (Rosengren et al. 1993).

In the Bieszczady NP three clusters of peat bogs can be distinguished, based on the distances between the bogs and the dispersal capacity of $F$. picea queens: in the east part (five peat bogs), in the north (three peat bogs) and in the west (two peat bogs). Within these clusters the exchange of flying sexuals (queens and males) is possible (Mabelis \& Chardon 2005). Each cluster forms a habitat network. The probability of $F$. picea to survive in this region is related to the size and quality of habitat patches which form part of such a habitat network.

About 25 years ago (in 1985) many nests of $F$. picea were found in peat bog number 5 , which belongs to the largest cluster (A.A. Mabelis, unpublished). At that time the quality of this peat bog was threatened by the presence of arable land, which was situated on a slope at higher level. This situation may have influenced the quality of the peat bog negatively. Especially nitrogen will affect Sphagnum vegetations (Limpens 2003) and hence the habitat of $F$. picea. This arable land was enlarged and drained a few years later (Malec 2009). In 1999, the Tarnawa District, where most peat bogs are situated, was included in the Bieszczady NP (Michalik et al. 2009). The arable land near peat bog number 5 was abandoned at that time and restoration measures, like removing nutrients by mowing the vegetation and cutting young trees, were applied. Nevertheless, in $2010 \mathrm{~F}$. picea was not found here anymore (Czechowski et al. 2002). Absence or low nest density of the species in this rather large peat bog may be due to a decline in habitat quality, because the distance to the nearest peat bog where the species occurs (number 4 ) is about $500 \mathrm{~m}$, which is within reach of a flying queen. The distance between the two peat bogs, where the species was found (numbers 4 and 6), is about $2 \mathrm{~km}$, which is also not too far for a $F$.picea queen to fly (Mabelis \& Chardon 2005).

The probability of occurrence of peat bog species cannot be related to the size of the reserves as given in Table 1, because only part of these areas is suitable as habitat for peat bog species, like $F$. picea. For example a great deal of the areas of peat bogs numbers 3,5 and 8 are covered by forest (Fig.2). Moreover, nearly all peat bogs in the Bieszczady Mts are covered by a dense dwarf shrub vegetation (Vaccinium uliginosum, V. vitis-idaea, V. myrtillus, Empetrum nigrum, Calluna vulgaris) and it is proved that the cover percentage of dwarf shrubs is negatively correlated with the cover of Sphagnum mosses (Malec 2009), which is optimal habitat of F. picea, at least in central and western Europe. The finding of Skwarra (1929) that Black bog ant nests were lacking in forested peat bog areas and in places where Calluna vulgaris was dominating is in agreement with our experience. Once a nest of $F$. picea was found also in a wet grassland, adjacent to peat bog number 4 , but this vegetation seems at best marginal habitat. However, Seifert (2004) suggested that in future $F$. picea may colonize wet grasslands in mountain ranges more often, due to climate change. The nest density of the Black bog ant is highest in places where the mosses Sphagnum magellanicum and S. rubellum are dominating. On such places the ants use small pieces of Sphagnum to build their nest. Sometimes the ants build their nest against a tussock of the moss Polytrichum, but the species was not found in places where Polytrichum species are dominating. According to Kaschek \& Königschulte (1982) a colony of $F$. picea will move to another place if Sphagnum will be pushed aside by Polytrichum.

In one peat bog $F$. lemani was found. This boreo-montane species inhabits open areas, forest glades and mountain meadows (Czechowski et al. 2002). In Poland it occurs only in mountainous areas in the south. At lower levels it prefers wet areas, like peat bogs.

$F$. truncorum can be judged as a North-Palaearctic species. The species is quite common in northern Europe, but it occurs less common in central Europe. Here it occurs in mountainous 
areas, as well as in lowlands. Its nests are generally widely dispersed and most often found in warm habitats (Mabelis \& Korczyńska 2001). Its occurrence in a peat bog is exceptional in western and middle Europe, but not uncommon in northern countries, like Finland (K. Vepsäläinen, pers. comm.).

The frequent occurrence of Lasius platythorax in peat bog number 2 may indicate some disturbance in the past. The area is covered by a dense dwarf shrub vegetation in which Empetrum nigrum and Calluna vulgaris are dominating, while the cover percentage of Sphagnum species is very low. Despite the extensive size of this open area (ca. 8 ha) only a few nests of other species were found. Can it be that the fire of 1925 , which lasted several years, has a long lasting effect on the flora and fauna of this peat bog?

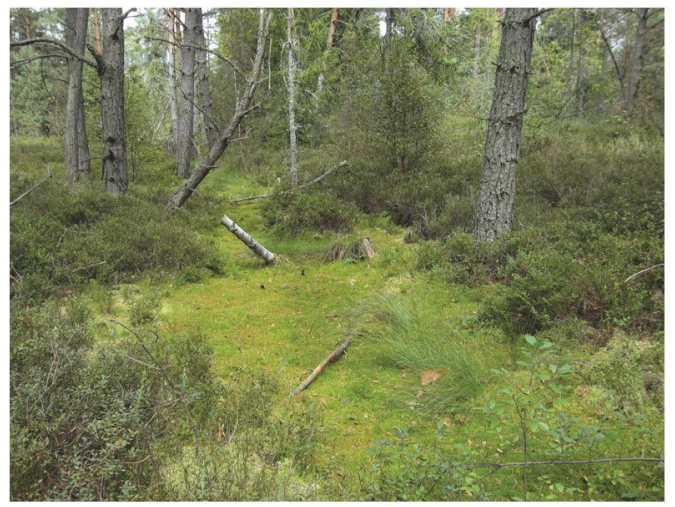

Fig.2. Peat bog Tarnawa Wyżna B (number 5) is partly covered by Pinus forest.

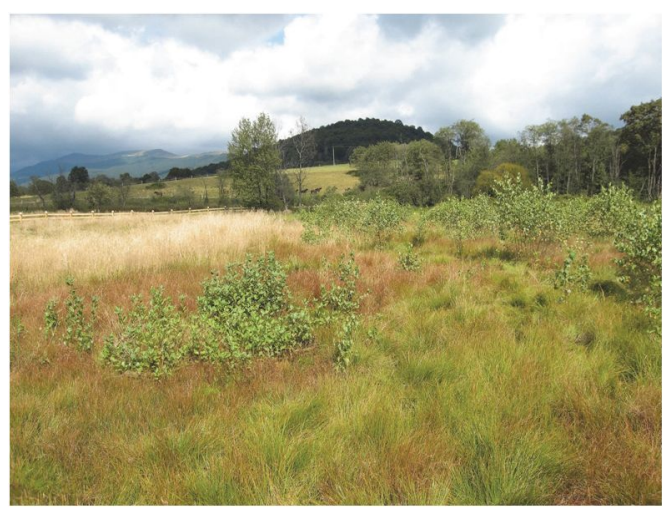

Fig.4. Wild shoots of Betula in peat bog Rezerwat Wolosate (number 9).

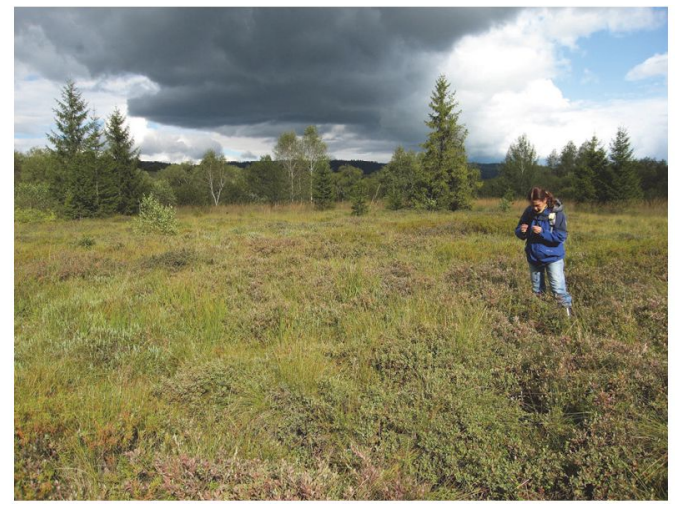

Fig.3. Dominance of dwarf shrubs in peat bog Tarnawa Wyżna A (number 4).

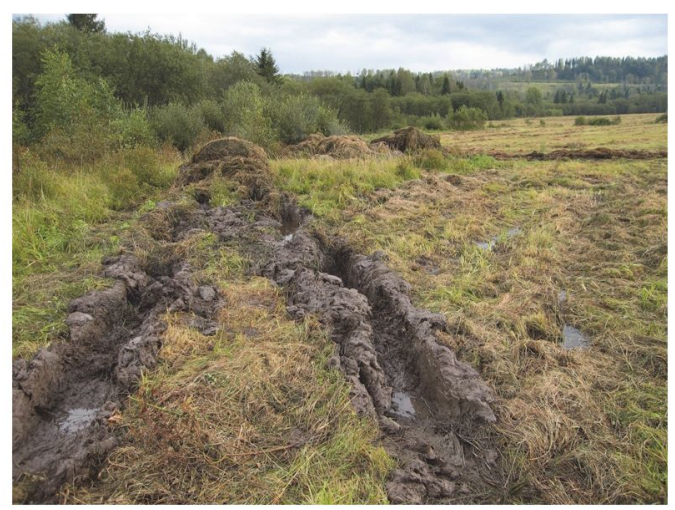

Fig. 5. Heavy machines have a negative effect on the soil fauna (Tarnawa Wyżna B).

In general the nest density of ants seems to be very low. This may be due to the fact that the peat bogs of Bieszczady are densely covered by dwarf shrubs, which make potential nesting places too shady (Fig.3). Nests of Myrmica species (M. ruginodis, M. rubra, M. scabrinodis) were only found in a few peat bogs. However, this infrequent recording may be due to the fact that they were more difficult to find in cold and rainy weather. These eurytopic species are generalists. They occur commonly in peat bogs, especially $M$. ruginodis and $M$. rubra. About 
40 years ago the ant fauna of peat bog number 9 was investigated by Parapura \& Pisarski (1971). At that time they found 10 ant species (Pisarski 1971). They did not find $F$. picea, but the occurrence of the fairly hygrophilic $F$. lemani may indicate that the habitat quality was better than ten years later when this bog was intensively drained by the state farm IGLOPOL. As a result the bog ecosystem suffered from drying up (Malec 2009). Desiccation will speed up the succession of the vegetation: bushes and trees will appear more quickly (Fig. 4).

\section{Management}

Since the peat bogs were included in the Bieszczady NP the management of these fragile ecosystems improved. Most important for bog conservation is the maintenance of an optimal hydrological condition. The groundwater level is regularly measured and some rewetting measures were applied. The agricultural land in the surroundings were converted into grassland, which will be mowed annually and not fertilized. In the past hay fields were mowed with a scythe, but nowadays machines are used to lower the costs. Heavy machines have a negative impact on the soft, wet organic soil (Fig. 5). As a result of soil compression the mineralization rate will increase and more nutrients will become available. Moreover, the natural loose peat structure of the topsoil will be destroyed, which has a negative effect on the soil fauna. The lighter the machines the better.

Nutrients are slowly removed from the grasslands by collecting the hay. However, nowadays the hay is not removed completely from the areas, like farmers did in the past when they could use the hay, but stored on hay stacks on the margins of grasslands. This promotes the development of a tall herb vegetation on the gradient between the mowed grassland and the peat bog area and this may have a negative effect on the peat bog ecosystem. The situation will improve if the plan to use hay as bio-fuel will be realized.

A regular removal of trees and bushes is recommended to keep the bog areas open. Their presence will not only have a shading effect on the herb and moss vegetation, but will also increase evapotranspiration and consequently lowering of the ground water table. The best option is to remove the felled wood from the bog areas. This is especially relevant in the case of small open areas, such as in the wooded peat bog number 3

\section{CONCLUSIONS AND RECOMMENDATIONS}

The Black bog ant was found in two peat bogs, which are situated near to each other. The local populations of these bogs may function as a source for other peat bogs in the neighborhood, which are part of a habitat network. The survival probability of the existing populations increased after improvement of the management of the surroundings. However, the encroachment of shrubs and trees is still a threatening factor.

Five other peat bogs (numbers 1, 2, 3, 9 and 10) are situated too far from the occupied ones for spontaneous colonization. Re-introduction of the Black bog ant could be considered, but first a more detailed study of the area should be carried out.

In the presented survey all ant species which we found are recorded. However, the total number of ant species found in a peat bog cannot be used to measure its biodiversity, as many of these species are generalists and are common in many habitat types. Only the presence of characteristic, i.e. stenotopic species, gives an indication of the contribution of a given bog site to the biodiversity of the region. Such data can also be used to evaluate the effect of management on the nature quality of bog ecosystems. Therefore we recommend to include $F$. picea in the monitoring program of the Bieszczady NP. 


\section{ACKNOWLEDGEMENTS}

Thanks to the collaboration with employees of the Bieszczady National Park it was possible to investigate all its peat bogs. We should like to mention Marek Holly, Stanislaw Kucharzyk, Michal Amarowicz and Hubert Pochyla. We are also thankful that Prof. Alexander Radchenko was helpful to check identifications and that Dr. Agata Klimkowska was willing to give valuable comment on the text. The inventory was supported by the Dutch Entomological Society.

\section{REFERENCES}

BÖNNER W. 1914. Formica fusca picea, eine Moorameise. Biologisches Centralblatt 34: 59-76.

CZECHOWSKI W., RADCHENKO A. \& CZECHOWSKA W. 2002. The ants (Hymenoptera, Formicidae) of Poland. Museum and Institute of Zoology PAS, Warszawa, $200 \mathrm{pp}$.

HACZEWSKI G., KUKULAK J. \& Bąk K. 2007. Budowa geologiczna i rzeźba Bieszczadzkiego Parku Narodowego (Geology and relief of the Bieszczady National Park). Prace Monograficzne 468: 1-156 [in Polish, English summary]. Wydawnictwo Naukowe Akademii Pedagogicznej w Krakowie.

HÖlLDOBLER B. \& WiLsON E.O. 1990. The Ants. Harvard University Press, Springer Verlag Berlin Heidelberg, 732 pp.

KASCHEK M. \& KÖNIGSCHULTE J. 1982. Untersuchungen zur Biologie der Ameisen im Diepholzer Moor soie Möglichkeiten des Biotoperhalts. Informationen zu Naturschutz und Landschaftspflege in Nordwestdeutschland 3: $239-282$.

MABELIS A.A. \& KORCZYiśsKA J. 2001. Dispersal for survival: some observations on the trunk ant (Formica truncorum Fabricius). Netherlands Journal of Zoology 51 (3): 299-321.

MABELIS A.A. \& Chardon P. 2005. Survival of the Black bog ant (Formica transkancasica Nasonov) in relation to the fragmentation of its habitat. Insect Conservation 9: 95-108.

MALEC M. 2009. Ocena procesu torfotwórczego na wybranych torfowiskach wysokich w Bieszczadzkim Parku Narodowym (Evaluation of peat-formation process of selected raised peat-bogs in the Bieszczady National Park). Roczniki Bieszczadzkie 17 : 243-252. [In Polish, English summary]

MAREK S. \& PALCZYŃSKI A. 1962.Torfowiska wysokie w Bieszezadach Zachodnich. Zeszyty Problemowe Postępów Nauk Rolniczych 34: 254-294.

MiCHALIK S., SZARY A. \& KUCHARZYK S. 2009. Charakterystyka roślinności na terenie obwodu ochronnego Tarnawa w Bieszczadzkim Parku Narodowym nad gómym Sanem (Characteristic of vegetation in Protected District Tarnawa at upper San river in the Bieszczady National Park). Roczniki Bieszczadzkie 17: 189-216 [in Polish, English summary]

LIMPENS J. 2003. Prospects for Sphagnum - bogs subject to high nitrogen deposition. Thesis, Wageningen University, The Netherlands, $143 \mathrm{pp}$.

PAMLLO P. 1982. Genetic population structure in polygynous Formica ants. Heridity 48 (1): 95-106.

PARAPURA E. \& Pisarski B. 1971. Mrówki (Hymenoptera, Formicidae) Bieszczadów. Fragmenta Faunistica 17(13): 319-356 [in Polish, French summary].

PISARSKI B. 1971. Charakterystyka zoologiczna środowisk Bieszezadów Zachodnich (Zoologische Charakteristik der Landbiotopen vom Bieszczady - Gebirge). Fragmenta Faunistica 17 (2): 23-30 [in Polish, German summary].

ROSENGREN R., SUNDSTRÖM L. \& FORTELIUS W. 1993. Monogyny and polygyny in Formica ants: the result of alternative dispersal tactics. In: Keller L. (ed.), Queen number and sociality in Insects, pp. 308-332. Oxford University Press, Oxford, 448 pp.

SEIFERT B. 2004. The "Black bog ant" Formica picea Nylander, 1846 - a species different from Formica candida Smith, 1878 (Hymenoptera: Formicidae). Myrmecologische Nachrichten 6: 29-38.

SKWARRA E. 1929. Formica fusca-picea Nyl. als Moorameise. Biologische Anzeiger 82: 46-55.

VERBOOM J. \& LANKESTER K. 1991. Linking local and regional dynamics in stochastic metapopulation models. Biological Journal of the Linnean Society 42: 39-55.

\section{STRESZCZENIE}

\section{[Czy mrówka Formica picea Nyl. przetrwa w Bieszczadzkim Parku Narodowym (pd.- wsch. Polska)?]}

Przeprowadzono inwentaryzację mrówki Formica picea na torfowiskach Bieszczadzkiego Parku Narodowego, aby ocenić prawdopodobieństwo przetrwania tego gatunku w poludniowowschodniej Polsce. Wyróżniono trzy zawierające sieć torfowisk obszary, które są zbyt oddalone od siebie, by możliwa byla ich (re)kolonizacja przez latające królowe. Największy obszar zawiera pięć torfowisk, z których tylko na dwóch znaleziono $F$. picea. Gatunku tego nie stwierdzono na 
torfowiskach polożonych na pozostalych obszarach. Stan torfowisk zależy od strategii zarządzania. Obecnie największymi zagrożeniami dla torfowisk jest ich wysychanie oraz naplyw substancji odżywczych, co przyspiesza proces sukcesji roślinnej. Siedliska $F$. picea, na których w warstwie mchów wciąż dominuja gatunki z rodzaju Sphagnum, sa w wyniku tych procesów porastane krzewinkami.

Accepted: 25 September 2012 